УДК 336.225.676(477)

DOI https://doi.org/10.51989/NUL.2021.6.20

\title{
ТЕОРЕТИКО-ПРАВОВІ АСПЕКТИ УНИКНЕННЯ ПОДВІЙНОГО ОПОДАТКУВАННЯ В УКРАЇНI
}

\section{Слугоцька Вікторія Михайлівна,}

асистент кафедри соціально-економічних дисциплін

КЗВО «Барський гуманітарно-педагогічний коледж імені Михайла Грушевського»

Стаття $\epsilon$ дослідженням теоретико-правових аспектів уникнення подвійного оподаткування в Україні. Нами визначено, що подвійне оподаткування $\epsilon$ економічним явищем, коли конкретний суб'єкт оподатковується більше одного разу однорідним податком. Подвійне оподаткування може виникати, коли оподатковуються прибутки, отримані резидентами за кордоном; у разі змішаного порядку сплати податку; у випадку, коли оподатковується частина прибутків підприємства, які підлягають розподіленню. З'ясовано, що законодавство різних країн світу має певні особливості оподаткування доходів громадян і різниться рівнем розвитку та податковим навантаженням, унаслідок чого виникає міжнародне подвійне оподаткування. Правове регулювання діяльності держави у сфері уникнення подвійного оподаткування в Україні регулюється Податковим кодексом України та міжнародними угодами, які підписала наша держава. Недосконалість національного податкового законодавства призводить до подвійного оподаткування в межах країни. Досліджено, що в Україні основні положення щодо усунення подвійного оподаткування регулюються ст. 13 ПК України, відповідно до чого суми податків і зборів, сплачені за межами України, зараховуються під час розрахунку податків і зборів в Україні за правилами, встановленими цим Кодексом. Виокремлено, що подвійне оподаткування має негативні наслідки не тільки для держави, але і для платників податків. Воно призводить до того, що збільшується податковий тягар у кілька разів та виникають додаткові податкові зобов'язання для платника, унаслідок чого скорочується прибуток і зникає зацікавленість платника у господарській діяльності. У межах національного законодавства інструментом вирішення проблеми подвійного оподаткування найчастіше є так звані податковий кредит і податкова знижка. Визначено, що застосування податкового кредиту зумовлює ситуацію, за якої податки, сплачені іноземними державами, прирівнюються до податків своєї держави. Під податковою знижкою розуміють податок, сплачений в якості витрат, на які зменшується сума доходів, що підлягають оподаткуванню.

Ключові слова: подвійне оподаткування, фінансові операції, Податковий кодекс України, міжнародні угоди, податкове право.

\section{Slugotska Victoria. Theoretical and legal aspects of avoidance of double taxation in Ukraine}

The article is a study of theoretical and legal aspects of avoiding double taxation in Ukraine. We have determined that double taxation is an economic phenomenon when a particular entity is taxed more than once by a homogeneous tax. Double taxation may occur when income received by residents abroad is taxed; with a mixed order of tax payment; when part of the profits of the enterprise to be distributed is taxed. It was found that the laws of different countries of the world have certain features of personal income taxation and differ in the level of development and tax burden, as a result, there is an international double taxation. Legal regulation of the state's activities in the field of avoidance of double taxation in Ukraine is regulated by the Tax Code of Ukraine and international agreements signed by our state. The imperfection of national tax legislation leads to double taxation within the country. It is investigated that the main provisions of Ukraine on the elimination of double taxation are governed by Art. 13 of the Tax Code of Ukraine, according to which the amounts of taxes and fees paid outside Ukraine are credited during the calculation of taxes on fees in Ukraine according to the rules established by this Code. It is pointed out that double taxation has negative consequences not only for the state but also for taxpayers. As a result, the tax burden increases several times and additional tax liabilities arise for the taxpayer, and as a result, profits are reduced and interest in the economic activity of the latter disappears. Within the framework of national fiscal legislation, the so-called tax credit and tax rebate are often the tools for solving the problem of double taxation. It is determined 
that the application of a tax credit determines the situation in which taxes paid by foreign states are equated to the taxes of their state. A tax rebate is a tax that is paid as an expense that reduces the amount of taxable income. It has been found that the double taxation convention is currently the most effective tool in the fight against double taxation.

Key words: double taxation, financial transactions, Tax Code of Ukraine, international agreements, tax law.

Актуальність проблеми дослідження. В умовах посилення процесів глобалізації у світовому економічному просторі помітно зросла зацікавленість національних суб'єктів господарювання у поширенні своєї діяльності на закордонний ринок. Нині добробут країни найчастіше залежить від обсягу інвестицій у національну економіку і створення сприятливого клімату щодо цього. Саме тому у запобіганні подвійного оподаткування доходів майна чи активів зацікавлені не тільки самі платники податку, але і держава загалом. Слід зазначити, що подвійне оподаткування збільшує податкове навантаження на юридичних і фізичних осіб, що, у свою чергу, призводить до скорочення їхніх прибутків або доходів і зникнення зацікавленості до здійснення підприємницької діяльності останніх, а це, відповідно, стримує розвиток економіки держави, спричинюючи зростання цін на товари і послуги тощо.

Аналіз останніх досліджень і публікацій. Окремі проблемні питання уникнення подвійного оподаткування досліджувались у наукових працях Ю. Г. Дем'янчука, В. В. Карпова, Л. Л. Лазебник, О. І. Остапенка, Н.А.Падейського, Л. А. Савченко, Є. Я. Сорокіної, Г. П. Толстоп'ятенко, А. А. Шакирянова та багатьох інших. Втім, незважаючи на чималу кількість наукових здобутків, в юридичній літературі малодослідженими $€$ теоретико-правові проблеми усунення подвійного оподаткування в Україні.

Мета дослідження - аналіз сутності подвійного оподаткування та розкриття теоретико-правових проблем усунення подвійного оподаткування в Україні.

Об'єкт дослідження - подвійне оподаткування в Україні.

Предмет дослідження - визначення ключових аспектів уникнення подвійного оподаткування в Україні.

Виклад основного матеріалу. Зростання економіки і торгівлі як на території Укра- їни, так і за їі межами призвело до появи «подвійного оподаткування». 3 одного боку, в Україні відмічено високий рівень тіньової економіки, ухилення від сплати податків, низький рівень культури оподаткування вітчизняних платників, а з іншого боку, держава прагне забезпечити необхідні фінансові ресурси для бюджету та потребує пошуку дієвого механізму уникнення подвійного оподаткування. Законодавство різних країн світу має певні особливості оподаткування доходів громадян, а рівень розвитку країн і податкове навантаження $\epsilon$ різними, що призводить до міжнародного подвійного оподаткування.

У XX столітті міждержавна взаємодія 3 питань уникнення подвійного оподаткування вийшла на якісно новий рівень, що проявилося, зокрема, у діяльності такої міжнародної організації, як Ліга Націй. У межах відповідної організації ще у 1928 році спільними зусиллями державчленів сконструйовано першу модельну конвенцію двостороннього характеру, яка стосується проблематики уникнення подвійного оподаткування [4]. Загалом слід зазначити, що під егідою Ліги Націй розроблено 4 моделі типових конвенцій, які спрямовувалися на подолання проблеми подвійного оподаткування, та стосувалися, зокрема, таких питань:

- уникнення подвійного оподаткування спадкового майна;

- уникнення подвійного оподаткування прямими за своїм характером податками і зборами;

- міжвідомча співпраця (адміністративна допомога) з питань оподаткування;

- допомога у стягненні загальнообов'язкових платежів податкового характеру [1, с. 34].

Загалом упродовж другої половини XX століття між країнами-членами $\in C$ було укладено 70 міжнародних договорів, які стосуються проблематики усунення подвійного оподаткування [4]. 
Унаслідок недосконалості національного податкового законодавства виникає подвійне оподаткування в межах країни [2, с. 574-575]. У податковому законодавстві кожної країни, окрім внутрішнього, можна виділити також відносини, які будь-яким чином залучають іноземні фактори. До цього зв'язку належать усі ситуації, які відбуваються у певній країні, але об'єктом оподаткування або платником податку $\epsilon$ іноземна держава, а також поведінка громадян інших країн. У таких випадках виникає проблема подвійного оподаткування, тобто оподаткування певного податкового об'єкта або відповідного платника тим самим податком за один податковий період. Унаслідок цього виникає ідентичність податкового платежу, тотожність об'єкта і суб'єкта оподаткування, термінів сплати податків [13, с. 98].

Внутрішнє подвійне оподаткування можна вирізнити як горизонтальне і вертикальне. Під вертикальним подвійним оподаткуванням розуміють сплату однакового податку на державному і місцевому рівнях. Горизонтальне подвійне оподаткування виникає через різницю у визначенні об'єкта оподаткування на одному адміністративному рівні [14].

Проблема подвійного оподаткування виникає у таких випадках:

- оподаткування іноземних доходів, отриманих резидентами (у цьому випадку резидент повинен сплатити податки як на території держави фактичного здійснення своєї господарської діяльності, так і на території держави, на якій він $\in$ резидентом);

- у разі змішаного порядку сплати податку (суб'єкти господарювання мають сплачувати податок, а також подавати декларацію про доходи у різних країнах);

- оподаткування частини прибутку підприємств, що розподіляється (водночас прибуток, що розподіляється, обкладають податком удвічі). У цьому випадку можливим $є$ використання різних ставок для розподіленого і нерозподіленого прибутку, повне або часткове звільнення від оподаткування або розподіленого прибутку [2, с. 574].

Під подвійним оподаткуванням розуміють оподаткування одного податкового об'єкта (окремого платника) одним (чи аналогічним) податком або збором за той самий період (податковий період) [10]. щодо законодавчого аспекту уникнення подвійного оподаткування, то відповідно до статті 103 Податкового кодексу України застосування правил міжнародного договору України здійснюється шляхом звільнення від оподаткування доходів із джерелом їх походження з України, зменшення ставки податку або шляхом повернення різниці між сплаченою сумою податку і сумою, яку нерезиденту потрібно сплатити відповідно до міжнародного договору України [10, с. 103].

Подолання проблеми внутрішнього подвійного оподаткування - прерогатива державної податкової політики. Зазвичай вона розв'язується шляхом укладення міжнародних двосторонніх або багатосторонніх угод. Україна має податкові конвенції із понад 70 країнами світу та активно розширює межі міжнародної співпраці у податковій сфері [5, с. 143]. Норми Податкового Кодексу (ПК) України, які регулюють діяльність держави у сфері уникнення подвійного оподаткування, залежно від характеру регулювання цих відносин можна умовно поділити на дві групи: правовстановлюючі та правозастосовні (рис. 1).

Норми ПК України спрямовані на те, щоб уникати подвійного оподаткування та забезпечувати права платників податків. Наприклад, в умовах 
здійснення зовнішньоекономічної діяльності українськими підприємствами досить часто здійснюються операції із виплати доходів нерезидентам, які мають оподатковуватися в Україні відповідно до положень ст. 141 ПК України [10]. Українське підприємство, яке $\epsilon$ податковим агентом нерезидента в Україні, має утримувати відповідну суму податку з такого доходу, враховуючи вимоги міжнародного договору України про уникнення подвійного оподаткування, укладеного із країною резидентства контрагента.

Зовнішнє або міжнародне подвійне оподаткування виникає у випадку обкладання податками однієї особи відносно однієї бази у більш ніж двох державах за той самий період. Таке оподаткування виникає у разі:

- визнання того ж самого суб'єкта (юридичної або фізичної особи) резидентом у двох або більше країнах;

- обкладення того ж самого доходу/ майна в одній державі на підставі критерію резидентства, а в іншій - відповідно до законодавства про джерело доходів;

- визначення того самого доходу/ майна таким, що має джерело походження у двох або більше країнах;

- різних підходів до порядку та розмірів зарахування понесених витрат [9, с. 3].

Для того, щоб дослідити правову природу способів та методів усунення міжнародного подвійного оподаткування, насамперед важливо встановити методи уникнення міжнародного подвійного оподаткування [10].

Методи усунення міжнародного подвійного оподаткування - це самостійний комплексний інститут, який застосовують задля того, щоб повністю ліквідувати явище подвійного оподаткування після застосування інституту резиденства або інституту обмеженої податкової юрисдикції і спеціальних правил про звільнення від оподаткування окремих видів доходів [10, с. 77].

Найлояльнішим методом $€$ метод звільнення. Основна суть його полягає в тому, що країна, яка $\epsilon$ джерелом отримання доходу, володіє виключними правами на оподаткування доходів, отриманих на ії території, тоді як держава резиденства відмовляється від свого права на оподаткування доходу своїх резидентів, отрима- ного на території інших країн, тобто від оподаткування звільняються певні типи доходів, отримані резидентом на території інших країн [8, с. 251]. Визначений метод закріплено у Конвенціях між урядами України і Франції [6], Молдови, Польщі про уникнення подвійного оподаткування доходів і майна та попередження податкового ухилення [7].

Наступним методом $€$ метод податкового кредиту, відповідно до якого платники податків у країнах із вищими податковими ставками, які отримують доходи із країн із нижчими податковими ставками, сплачуватимуть своїй країні лише суму перевищення податків своєї країни над податками іншої країни. Якщо ж доходи платника податків за кордоном оподатковуються за ставкою, вищою, ніж у своїй країні, то ані відшкодування, ані компенсації для нього не передбачається. У ст. 13.2 ПК України вказано, що під час визначення об'єкта та / або бази оподаткування витрати, здійснені резидентом України (крім фізичних осіб) у зв'язку з отриманням доходів із джерел походження за межами України, враховуються у порядку і розмірах, установлених ПК України [10].

Третім методом $\epsilon$ метод вирахування, відповідно до якого податок, який сплачується на території іншої країни, дорівнюється до стандартних податкових вирахувань, тобто вираховується із бази оподаткування. У ст. 13.1 ПК України вказано, що для отримання права на зарахування податків і зборів, сплачених за межами України, платник зобов'язаний отримати від державного органу країни, де отримується такий дохід (прибуток), уповноваженого справляти такий податок і довідку про суму сплаченого податку і збору, а також про базу та / або об'єкт оподаткування [10].

Четвертим методом $€$ метод податкової знижки, відповідно до якого податок сплачують як витрати, на які зменшується сума доходів, що підлягають оподаткуванню. Отже, задля того, щоб усунути подвійне оподаткування, можна оперувати не самими податками, а об'єктом оподаткування [3]. У ст. 13.4 ст. 13 ПК України зазначено, що суми податків і зборів, сплачених за межами України, зараховуються під час розрахунку податків і зборів 
в Україні за правилами, встановленими ПК України.

Конвенції про уникнення подвійного оподаткування наразі $\epsilon$ найбільш дієвим інструментом боротьби із подвійним оподаткуванням та ухиленням від сплати податків у міжнародних податкових відносинах. Вони регулюють відносини між державами, тобто прагнуть до справедливого розподілу податкових надходжень, до створення стабільного правового середовища або запобігання дискримінації іноземців.

Організація Економічного Співробітництва та Розвитку розробила План із протидії розмивання бази оподаткування та виведення прибутку з-під оподаткування - BEPS (Base Erosion and Profit Shifting). BEPS - це стратегії запобігання механізмам податкового планування, які використовують прогалини та невідповідність податковим правилам для штучного переміщення прибутку у місцях із низьким рівнем оподаткування або без оподаткування.

Україна ж узяла курс на адаптацію окремих принципів BEPS до національного законодавства. Із метою реалізації окремих принципів потрібно:

1) запроваджувати правила оподаткування контрольованих іноземних компаній (Крок 3 BEPS);

2) запроваджувати додаткову звітність із трансфертного ціноутворення для міжнародних груп компаній (Крок 13 BEPS);

3) удосконалювати правила щодо обмеження витрат за фінансовими операціями 3 пов'язаними особами - нерезидентами (Крок 4 ВEPS);
4) запобігати зловживанню через застосування договорів про усунення подвійного оподаткування (Крок 6 BEPS);

5) запобігати уникненню статусу постійного представництва (Крок 7 BEPS);

6) приєднатися до автоматичного обміну фінансовою інформацією [12].

Слід зазначити, що 28 лютого 2019 року Верховна Рада України ухвалила Закон України «Про ратифікацію Багатосторонньої конвенції про виконання заходів, які стосуються угод про оподаткування, з метою протидії розмиванню бази оподаткування та виведенню прибутку з-під оподаткування» («MLI») [11].

Висновки. Отже, проблема подвійного оподаткування продовжує залишатися досить актуальною у сучасних умовах розвитку держав та їхнього економічного і правового співробітництва, спричинюючи значні перешкоди для юридичних осіб, які отримують доходи за кордоном або які володіють майном за кордоном. Завдяки аналізу двосторонніх угод України про уникнення подвійного оподаткування ми можемо зробити висновок, що визначені податкові угоди $є$ основними засобами боротьби із подвійним оподаткуванням, адже в них містяться всі ключові положення, які допомагають платникам податків належним чином виконувати свій податковий обов'язок без обкладання непомірним податковим тягарем. Задля підвищення ефективності впровадження міжнародних норм щодо уникнення подвійного оподаткування слід чітко визначити термінологію та узгодити іï із нормами національного і міжнародного законодавства.

\section{ЛITЕРАТУРА:}

1. Дубовик О. Ю. Проблеми усунення подвійного оподаткування в Україні. URL: http:// dspace.oneu.edu.ua/jspui/bitstream/123456789/3829/1/Проблеми\%20усунення\%20подвійного\%20оподаткування\%20в\%20Україні.pdf.

2. Воронина Н.В., Бабанин В.А. Двойное налогообложение и уклонение от уплаты налогов как проблема международного характера. Все для бухгалтера. 2007. № 10. С. 33-39.

3. Городниченко Ю. В. Подвійне оподаткування, сутність та методи його усунення. Економіка і суспільство. 2017. № 10. С. 574-575.

4. Шмиголь Н. М. Уникнення подвійного оподаткування. Теорія та практика ефективного використання. Економіка та підприємництво. 2013. № 5. С. 98.

5. Baker P. L. An Analysis of Double Taxation Treaties and their Effect on Foreign Direct Investment. International Journal of the Economics of Business. 2014. URL: https:// www.tandfonline.com/doi/abs/10.1080/13571516.2014.968454.

6. Податковий кодекс України: Закон України №2755-VI від 02.12.2010р. Відомості Верховної Ради. 2011. №№ 13-17. Ст. 11. URL: http://zakon.rada.gov.ua/cgibin/laws/main. cgi?nreg=2755-17. 
7. Збірник статей здобувачів вищої освіти другого (магістерського) рівня Навчально-наукового інституту права Університету ДФС України: у 4 ч. Ч. 1. Ірпінь: Університет ДФС України, 2020. 268 с.

8. Пархуць В. В. Природа подвійного оподаткування. Наука онлайн: Міжнародний електронний науковий журнал. 2020. № 12. С. 1-5.

9. Максак О. І. Щодо питання про підстави усунення зовнішнього оподаткування. 2009. № 2. С. 250-253.

10. Конвенція між Урядом України і Урядом Республіки Молдова про уникнення подвійного оподаткування доходів і майна та попередження податкових ухилень. URL: https:// zakon.rada.gov.ua/rada/show/498_62.

11. Конвенція між Урядом України і Урядом Республіки Польща про уникнення подвійного оподаткування доходів і майна та попередження податкових ухилень. URL: https:// zakon.rada.gov.ua/rada/show/616_168.

12. Демянчук Ю. Г. Методики уникнення міжнародного подвійного оподаткування. URL: https://lj.oa.edu.ua/articles/2011/n1/11dyhmpo.pdf.

13. Проєкт BEPS. Розмивання податкової бази та виведення прибутку з-під оподаткування. URL: https://www2.deloitte.com/ua/uk/pages/tax/articles/aboutbeps.html.

14. Про ратифікацію Багатосторонньої конвенції про виконання заходів, які стосуються угод про оподаткування, з метою протидії розмиванню бази оподаткування та виведенню прибутку з-під оподаткування: Закон України від 28 лютого 2019 р. № 2692-VIII. URL: https://zakon.rada.gov.ua/laws/show/2692-19\#n2. 